\title{
JUURNAL.RU
}

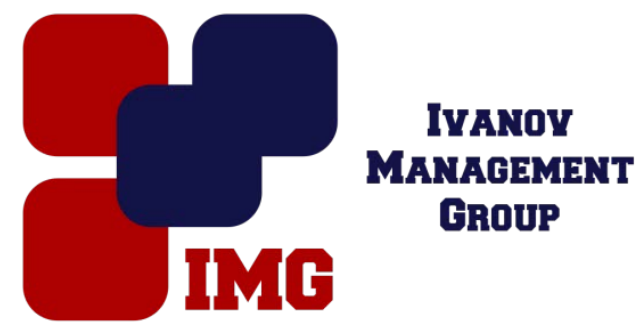

Покостяева А.А.

Иркутский Государственный Университет Иркутск, Россия

doi: 10.18411/lj-28-02-2017-2-07

idsp 000001:lj-28-02-2017-2-07

\section{Российско-китайские экономические отношения на современном этапе и перспективы их развития в ближайшие годы}

\section{Аннотация}

Главная цель данной статьи заключается в выяснении основных задач и целей России и КНР, которые они преследуют, взаимодействуя друг с другом. Также здесь рассмотрены причины ориентированности РФ на торговые отношения со странами Востока. Проанализированы нерешенные проблемы экономического характера и их последствия для данных торговых отношений. Выявлены широкомасштабные интересы обеих стран, а кроме того, обоснована необходимость совместного, взаимовыгодного использования ресурсов.

Ключевые слова: Российская Федерация, КНР, экономическое партнерство, российский рубль, торговые отношения, современное состояние, перспективы на будущее.

Pokostyaeva A.A.

Russian-Chinese economic relationships at the current stage and prospects of their development in the following years

Abstract

The main purpose of this article is to clarify the basic objectives and goals of Russia and China, which they pursue, interacting with each other. There is also considered causes orientation of the Russian Federation on trade relations with the countries of the East. Analyzed unresolved economic problems and their implications for trade relationships. Revealed wide-ranging interests of both countries, and in addition, the necessity of a joint and mutually beneficial use of resources.

KeyWords: Russian Federation, China, the economic partnership, the Russian ruble, trade relations, the current state of and prospects for the future.

В настоящее время ученые всего мира пессимистично оценивают состояние мировой экономики из-за многочисленных разногласий между странами. Российская Федерация в этом отношении находится в весьма затруднительном положении, так как вопрос преодоления нефтегазовой зависимости как главных продуктов экспорта, по сей день остается открытым. Ввиду ухудшения 
взаимоотношений между двумя крупными державами, а именно России и США, а также напряжения между Россией и странами Евросоюза, на данный момент экономика нашей страны более ориентирована на Восток, что неудивительно. Особенно в отношении КНР. Современный Китай - это быстро и динамично развивающаяся страна, стимулирующая развитие внутренних политических институтов [3], активно наращивающая свой мировой экспортный потенциал в рамках глобализирующейся мировой экономики [9], развивающая духовную составляющую хозяйственной культуры внутри страны [6] и активно трауслирующая свои ценности вовне [20].

Взаимоотношения России и Китая всегда отмечались наличием богатой, но при этом чрезвычайно сложной истории, периоды которой варьировались от тесного сближения стран в экономическом плане до разногласий, которые приводили к разрыву всяческих контактов.

Из истории мы можем наблюдать, что сопричастность экономики России и Китая имела место еще в эпоху становления торговых отношений азиатских и европейских стран, когда Великий шелковый путь играл огромное значение и был связующим звеном между двумя "разными мирами".

Наиболее контрастный и неоднозначный характер отношения двух стран носили в период становления СССР его вплоть до распада. Как раз-таки на конец эпохи Сталина, после его смерти, пришлась кульминация и резкое ухудшение не только контактов в экономической, но также и в других сферах.

Говоря о современном положении дел, безусловно, конфликт на Украине подтолкнул Россию к сближению с Китаем, что, однако, не означает отсутствия разногласий. Цели обеих стран заключаются в "расширенном сотрудничестве" в странах Средней Азии. Но камнем преткновения в таком случае может стать китайские инвестиции и возможность КНР стать кредитором стран - соседей России, которые некогда входили в состав СССР.

Вне зависимости от наличия различных интересов, обе страны преследуют и общие цели. Давно известно, что несмотря на динамичное развитие, Китай страна энергозатратная, ибо все ставки были сделаны на развитие таких отраслей. Зависимость КНР от нефти составляет 60\%. Россия, в этом случае, одна из наиболее богатых стран запасами нефти и газа, это является одни из связующих звеньев экономических отношений. Помимо этого, наибольшим спросом в Китае пользуются сельхозпродукция, полуфабрикаты, сырье для деревоперерабатывающей, химической, пищевой и легкой промышленности. Политики обеих стран понимают, что куда больше преимуществ может принести сотрудничество, нежели борьба, особенно ввиду географической близости, так как в мире и без того сейчас неспокойно и вооруженные конфликты не редкое явление в XXI веке. Именно поэтому РФ и КНР подписали в июле 2001 года договор о "Дружбе, добрососедстве и сотрудничестве" сроком на 20 лет. А в последние несколько лет активно обсуждался вопрос, неоднократно поднимаемый еще в XX веке - это строительство Трансконтинентального экономического моста, который связывал бы Россию со странами Востока, в том числе и с КНР.

Исследование и изучение российско-китайских отношений, а также проблем, связанных с ними, было и будет ещё долгое время актуальной темой, именно поэтому им занимаются такие видные ученые - востоковеды, эксперты по международным отношениям Восточной Азии, как: Галенович Ю.М. (российский китаевед, профессор, чье основное направление научных трудов заключалось в 
рассмотрении истории взаимоотношений между КНР и РФ), Лузянин С.Г. (эксперт по внешней политике КНР и истории Китая) и Б.Т. Кулик (один из главных сотрудников Института Дальнего Востока, посол). Вопросы китайского языка и письменности изучают Т.Е. Шишмарева [19], С.В. Стефановская [12], Е.А. Хамаева [15], И.В. Шаравьева [18], О.Ю. Воронина [4], Китаеведов объединяет растущая заинтересованность к Китаю, его культурным ценностям [1], историческим особенностям и, конечно же, современному положению в мире.

Однако, в настоящее время растет число не только видных ученых, но и простых людей по всему миру, находящихся еще в процессе обучения или работающих в других областях, которые в итоге решают посвятить свою жизнь востоковедению, выбирают китайский язык и впоследствии, начинают постигать тонкости культуры и традиции этой страны. Все это еще раз показывает нам, что место КНР в строительстве нового мирового экономического порядка огромно и нельзя с этим не считаться, поэтому молодые люди, надеясь на перспективное будущее и построение успешной карьеры, решают связать свое будущее именно с динамично развивающимся и подающим огромные надежды Китаем.

История развития торговых отношений между Россией и Китаем уже была затронута и кратко рассмотрена нами выше, теперь хотелось бы уделить внимание дальнейшим перспективам.

Затрагивая эту тему, мы можем обратиться к относительно недавно произошедшей ситуации. Многих россиян поразила новость о переговорах, где обсуждался вопрос приграничного сотрудничества в виде передачи в пользование Китаю на 49 лет земель Дальнего Востока. Если бы Путин дал согласие на реализацию этого проекта, мог возникнуть международный скандал. Фактически, от такой сделки РФ могла терпеть только убытки. КНР должны были платить 30 млн рублей в год. Эти деньги не решили бы никаких проблем нашего государства, но при этом в итоге мы лишились бы территории в 115 тысяч гектаров, земли дальнего Востока в конце концов были бы опустошены, никаких более сельскохозяйственных угодий, полезных ископаемых итд. Но договор так и не был заключён, а вся ситуация с обсуждением передачи плавно замята именно российской стороной. Поэтому мы можем сделать вывод, что несмотря на распространенное мнение ученых с Запада якобы "Китай формулирует, а Россия в основном признает его инициативы по развитию двустороннего партнерства", направленность взаимодействия России и Китая показывает значимое, высокое положение обеих стран в отношении внешнеполитических приоритетов между друг другом.

Таким образом, мы видим, что мнение экономистов всего мира расходится. Одни считают, что здесь уместно изречение "спят в одной кровати, но видят разные сны", и что Россия, что Китай преследуют разные, противоречивые друг для друга цели, которые в итоге станут камнем преткновения и разрушат этот и без того непрочный союз. Другие же убеждены, что уровень этих отношений беспрецедентно высок из-за ухудшения связей и почти максимально отсутствия влияния России на страны Запада. Вследствие этого альянс может просуществовать еще продолжительный период времени и принести выгоду для обеих стран. Положение в мире слишком нестабильно в наши дни, сложно дать однозначную оценку и сказать, к чему могут привести эти взаимоотношения. В мировой политике не существует друзей, так как любое государство прежде всего ставит свои национальные интересы. Не известно, как долго КНР будет нужна 
помощь РФ и через какой промежуток времени Китай сможет найти более дешевое сырье и других союзников, из сотрудничества с которыми можно извлечь больше выгоды.

Подводя итоги данной статьи, делаем следующие выводы: КНР и РФ в настоящее время представляют собой обычных стратегических партнеров, чей союз относительно непрочен. Но, так или иначе, эти отношения - одно из главенствующих направлений экономики и политики нашей страны. Широкомасштабные интересы обеих стран во многом совпадают, острые разногласия пока не наблюдались. В связи с этим, остается только надеяться на поддержку со стороны КНР еще в течение длительного промежутка времени, такой сильный и перспективный союзник сейчас будет нужен нашей стране. 


\section{Литература}

1. Адилханян Н.Л. Опыт выявления архетипических признаков антропоморфных духов трактата «Шань хай цзин» (на примере Си Ван Му (西王母) и Хоу И (后羿) // Культуры и языки стран Дальнего Востока: изучение и обучение. Иркутск: МГЛУ ЕАЛИ: 2014. С. 3-10.

2. Алексеев А.Д. Россия и Китай не союзники, но партнеры // Огонек. - 2001. - № 33.- с. 20.

3. Баринкова А.В., Кремнёв Е.В. Партийная система КНР в типологическом аспекте: однопартийность или неконкурентная многопартийность? // Crede Experto: транспорт, общество, образование, язык. 2015. № 3. С. 129-142.

4. Воронина О.Ю. История китайского языка в трактате Пань Юньчжуна // Научнопедагогический журнал Восточной Сибири Magister Dixit. 2014. № 4 (16). C. 18-24.

5. Гельбрас В.Г. Россия и Китай: вопросы собирания геоэкономических ресурсов. // Полис. - 2006. - № 2. - С.20.

6. Кобжицкая О.Г. Духовные основы хозяйственной культуры // Диссертация на соискание ученой степени кандидата философских наук / Иркутский государственный университет. Иркутск, 1999. 210 с.

7. Кремнёва Т.А., Ван Ланьцзюй. Китайский язык. начальный уровень. Иркутск: МГЛУ ЕАЛИ, 2015. $180 \mathrm{c.}$

8. Лукин А. Россия-Китай. // Международная жизнь.- 2000. - № 3. - С. 42.

9. Макеева С.Б. Особенности социологического осмысления процесса глобализации современного мирового сообщества // Сборник статей по итогам научноисследовательской работы института социально-политических систем Читинского государственного университет за 2009-2010 гг Чита, 2010. С. 15-23.

10. Пекинская декларация Российской Федерации и Китайской Народной Республики. // Проблемы Дальнего Востока, 2000, № 5, стр. 8.

11. Сергеев И. Российско - китайские совместные проекты // Эксперт. - 2000.- № 27. - с. 12-18.

12. Стефановская С.В. Способы семиотизации звукового мира // автореферат диссертации на соискание ученой степени кандидата филологических наук / Иркутский государственный лингвистический университет. Иркутск, 2012. -20 с.

13. Тимофеев, О.А. «Мягкие» методы международного влияния и трансформация внешнеполитической парадигмы КНР // Вестник ТОГУ. - 2009. - № 4.

14. Тимофеев О. Г. Сетевое издание Центра исследований и аналитики Фонда исторической перспективы. Государство и политика, http://www.perspektivy.info/rus/gos/rossijsko-

kitajskije_otnoshenija_na_sovremennom_etape_i_perspektivy_ih_razvitija_2014-12-15.htm

15. Хамаева Е.А. Семантика китайского имени собственного: опыт классификации // Современные проблемы гуманитарных и естественных наук материалы конференции молодых ученых. 2009. С. 191-193.

16. Хо О.А. «Вино» 酒 как ритуал в культуре Китая // Культуры и языки стран Дальнего Востока: изучение и обучение. Иркутск: МГЛУ ЕАЛИ: 2014. С. 282-290.

17. Холодны Е.А. Иносми.ру. Россия сегодня. Отношения России и Китая сложнее, чем кажется, http://inosmi.ru/world/20150607/228438125.html

18. Шаравьева И.В. Монадно-модусный подход как способ рассмотрения китайских письменных знаков // Вестник Иркутского государственного лингвистического университета. 2012. № 4. С. 151-155.

19. Шишмарева Т.Е., Терехова Н.В., Кремнёва Т.А. Базовые аспекты модели структурной линии развития китайской письменности в трактовке Ю.В. Бунакова // Успехи современной науки и образования. 2016. Т. 2. № 7. С. 121-123.

20. Veresova E., Kuznetsova O. «Soft Power» Concepts in Traditional Chinese Doctrine // Наука сегодня: вызовы и решения: материалы международной научно-практической конференции. Научный центр «Диспут». 2016. С. 185-186. 